\title{
次世代リチウムイオン電池用ケイ素系負極の創製と 電極一電解質界面の最適化
}

\author{
薄井洋行 ${ }^{1,2} \cdot$ 成田匡邦 ${ }^{1,2} \cdot$ 藤田佳宏 ${ }^{1,2} \cdot$ 坂口裕樹 ${ }^{1,2}$ \\ '鳥取大学大学院工学研究科化学・生物応用工学専攻 正680-8552 鳥取県鳥取市湖山町南 4-101 \\ 鳥取大学工学部附属グリーン・サスティナブル・国680-8552 鳥取県鳥取市湖山町南 4-101 \\ ケミストリー研究センター
}

（2015 年 2 月 13 日受付 ; 2015 年 4 月 7 日掲載決定）

\section{Silicon-Based Anodes and Optimized Interface between Electrodes and Electrolytes for Next Generation Lithium-Ion Battery}

\author{
Hiroyuki Usui ${ }^{1,2}$, Masakuni Narita ${ }^{1,2}$, Yoshihiro FujIta ${ }^{1,2}$ and Hiroki SAKAgUCHI ${ }^{1,2}$ \\ ${ }^{1}$ Department of Chemistry and Biotechnology, Graduate School of Engineering, Tottori University, \\ 4-101 Minami, Koyama-cho, Tottori 680-8552 \\ ${ }^{2}$ Center for Research on Green Sustainable Chemistry, Tottori University, \\ 4-101 Minami, Koyama-cho, Tottori 680-8552
}

(Received February 13, 2015 ; Accepted April 7, 2015)

\begin{abstract}
We prepared Ni-P-coated Si particles by an electroless deposition method as an anode material of a high-performance Li-ion battery, and optimized the interface between electrode and electrolyte by using an ionic liquid electrolyte. For the improvement of an adhesion between $\mathrm{Ni}-\mathrm{P}$ and $\mathrm{Si}$, we carried out a surface roughening of uncoated $\mathrm{Si}$ by a chemical etching, and then a thermal treatment of $\mathrm{Ni}$-P-coated $\mathrm{Si}$ particles. Galvanostatic charge-discharge tests were performed for Ni-P-coated Si composite electrodes prepared by a gas-deposition method using the resulting particles. The results showed that an enhanced anode performance was obtained for the electrode of annealed $\mathrm{Ni}-\mathrm{P} /($ etched $\mathrm{Si}$ ) in a conventional organic electrolyte due to the improved adhesion. In addition, the electrode exhibited a significantly stable cyclability in the ionic liquid electrolyte : a high discharge capacity of $1000 \mathrm{~mA} \mathrm{~h} \mathrm{~g}^{-1}$ was maintained with no capacity fading for 1100 cycles.
\end{abstract}

KEYWORDS : Si anodes, Li-ion battery, Ni-P, electroless deposition, ionic liquid electrolytes

\section{1.は じめに}

電気自動車のみならず再生可能エネルギーの電力貯蔵 用として, リチウムイオン電池の重要性は高まる一方で あり, その高エネルギー密度化への要求が一層強くなっ ている。次世代の負極活物質として, ケイ素 $(\mathrm{Si})$ は従 来用いられてきた黒鉛の 10 倍以上もの高い理論容量を 有することから非常に魅力的な材料ではある。しかしな がら, 充放電の際の $\mathrm{Si}$ と $\mathrm{Li}$ との合金化一脱合金化にと

\footnotetext{
†第 34 回表面科学学術講演会（2014 年 11 月 6 日〜 8 日） にて発表

E-mail : sakaguch@chem.tottori-u.ac.jp
}

もなう激しい体積変化が電極活物質層の崩壊を招くた め, Si 負極は充放電サイクル寿命にそしいという問題 を有する。このそしいサイクル安定性を改善させる意図 で Si を他の元素と化合物化させるとその容量は著しく 損なわれてしまう。したがって，Si が潜在的に有する 高容量を活かすためにはこれを単体として活物質に用い つつ，その欠点を補う工夫を図る必要がある。

われわれは Si とその欠点を補う活物質とを複合化さ せることこそがこの問題の解決法であると考え, 独自の 電極作製法であるガスデポジション（GD）法 ${ }^{1,2}$ を用い 種々の金属 ${ }^{3 \sim 7)}$ ・合金 ${ }^{8 \sim 13)} \cdot$ 酸化物 $^{14,15)}$ 系材料を Si とコ ンポジット化させた新規負極を報告してきた。特に，無 
電解析出（ELD）法により $\mathrm{Ni}$ と $\mathrm{Ni}_{3} \mathrm{P}$ からなる混合相 （Ni-P）を $\mathrm{Si}$ 粒子の表面に斑点状に被覆した $\mathrm{Ni}-\mathrm{P} / \mathrm{Si}$ を 負極に用いることで, その電極性能が顕著に改善される

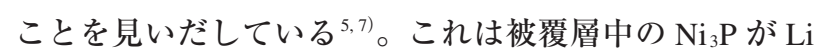
と適度な反応性を示すこと, また, 勒性を有する $\mathrm{Ni}$ と 硬い $\mathrm{Ni}_{3} \mathrm{P}$ が混在することで被覆層ひいては活物質層の 機械的性質が改善され, 電極の崩壊が起こりにくくなっ たためと思われる。ただし，この電極においても依然と して 150 サイクル程度までの容量衰退が見られる。この 原因として充放電を繰り返すうちに, Si の激しい体積 変化により $\mathrm{Ni}-\mathrm{P}$ 粒子がその表面から剥離してしまった 可能性がありこれへの対策が必要と考えた。

他方, 電解液は電池の性能を左右する要素材料であ る。われわれは $\mathrm{Si}$ の性能を効果的に引き出す電解液と してイオン液体の可能性を検討しており, 特定の構造を 有するカチオン・アニオンからなるイオン液体を電解液 に適用することで, 従来の一般的な有機電解液を用いた 場合よりも $\mathrm{Si}$ 系電極の負極特性が大きく向上すること をこれまでに見いだしている ${ }^{1620) 。 ~}$

本研究では, 被覆前の $\mathrm{Si}$ 粒子への表面粗化処理や被 覆後の $\mathrm{Ni}-\mathrm{P} / \mathrm{Si}$ 粒子に対する熱処理によって被覆層と $\mathrm{Si}$ 粒子との密着性を向上させ, これらが $\mathrm{Ni}-\mathrm{P}$ 被覆 $\mathrm{Si}$ コン ポジット電極の負極性能に与える影響を調べた。また, この電極に対しイオン液体電解液を適用することでさら なる長寿命化を試みた。

\section{2. 実 験 方 法}

表面粗化処理を行った Si 粒子に対して ELD 法を用い て Ni-P を被覆しこれに熱処理を行った試料（(株) NEOMAX マテリアル提供）を負極活物質とした。Si 粒 子の表面粗化はフッ酸を使用した化学エッチングにより 行い, 被覆後の熱処理は $800^{\circ} \mathrm{C}$ にて不活性ガス雲囲気下 で実施した。調製した試料に対して行った誘導結合プラ ズマ発光分析（ICP）で得られた $\mathrm{Si}: \mathrm{Ni}: \mathrm{P}$ の重量比は $94.9: 5.0: 0.1 \mathrm{wt} . \%$ であり, このことから著者らが以前 調製した試料 ${ }^{5,7)}$ と同様に $\mathrm{Ni}-\mathrm{P}$ 被覆層は $\mathrm{Ni}$ と $\mathrm{Ni}_{3} \mathrm{P}$ から なる混合相であることを確認した。試料の結晶構造と表 面形状を，それぞれX 線回折（XRD）と走查型電子顕 微鏡（SEM）観察により調べた。

電極の作製は GD 法により行った。本手法は活物質粉 末をキャリアガスを用いてエアロゾル化しノズルから噴 射して基板に高速で衝突させ膜化するものである。従来 法とは異なり副反応の原因となる導電助剤・結着剂を使 用しないため, 活物質本来の性質を直接調査できる特長 を持つ。製膜はキャリアガスに $\mathrm{Ar}(4 \mathrm{~N})$ を用い, 差圧 $7.0 \times 105 \mathrm{~Pa}$ ，ノズル径 $0.8 \mathrm{~mm}$, ノズル一基板間距離 10 $\mathrm{mm}$ の条件で銅䈃集電体上に行った。

得られた電極を試験極とし, 対極に $\mathrm{Li}$ 䇴, 従来の有 機溶媒系電解液として Propylene carbonate (PC) に対し Lithium bis (trifluoromethanesulfonyl) amide (LiTFSA) を濃度 $1 \mathrm{M}$ となるように溶解させたものを用い試験セ ルを構築した。また, イオン液体電解液には, $1 \mathrm{M}$ LiTFSA/ $N$-methyl- $N$-propylpyrrolidinium bis (fluorosulfonyl）amide（Py13-FSA）を使用した。充放電試験は 電位幅 $0.005 \sim 2.000 \mathrm{~V}$ vs. $\mathrm{Li} / \mathrm{Li}^{+}$, 電流密度 $1.4 \mathrm{~A} \mathrm{~g}^{-1}$ (0.4C) の条件で行った。また, 充電 (Li挿入) 容量を $1000 \mathrm{~mA} \mathrm{~h} \mathrm{~g}^{-1}$ となるように規制した試験 $(0.8 \mathrm{C})$ も実 施した。

\section{3. 結 果 と考察}

\section{3. $1 \mathrm{Ni}-\mathrm{P} / \mathrm{Si}$ 粒子の結晶構造と表面形状}

Fig. 1 にエッチング処理を行っていない Si 粒子上に $\mathrm{Ni}-\mathrm{P}$ を被覆した粉末の熱処理前後の XRD パターンの変 化を示す。いずれの試料からも $\mathrm{Si}$ と Ni に帰属される回 折ピークを確認した。 $\mathrm{Ni}_{3} \mathrm{P}$ のピークが出現していない

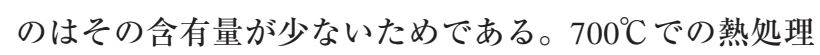

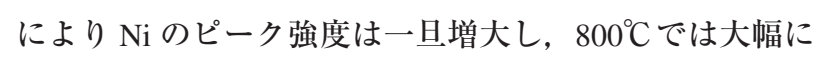
減少した。これは $700^{\circ} \mathrm{C}$ までは温度の上昇にともない $\mathrm{Ni}$ の結晶化が進むが， $800^{\circ} \mathrm{C}$ まで熱処理温度を上げると被 覆層中の $\mathrm{Ni}$ が $\mathrm{Si}$ 粒子内に拡散したためと考元られる。 同様の熱処理により $\mathrm{Ni}$ が $\mathrm{Si}$ に拡散し $\mathrm{NiSi}$ や $\mathrm{NiSi}_{2}$ の界 面相を形成する報告がある ${ }^{21,22)}$ 。本研究においてもこの ような界面相の形成が示唆され，これにより $\mathrm{Ni}-\mathrm{P}$ 被覆

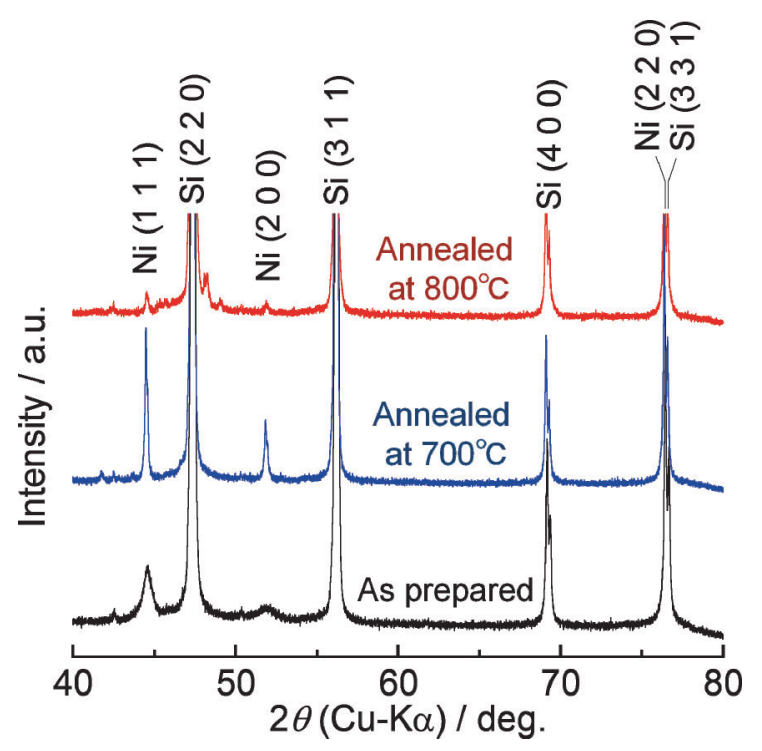

Fig. 1. (color online). XRD patterns of $\mathrm{Ni}-\mathrm{P} / \mathrm{Si}$ active material powders after annealing treatments at $700^{\circ} \mathrm{C}$ and $800^{\circ} \mathrm{C}$. 

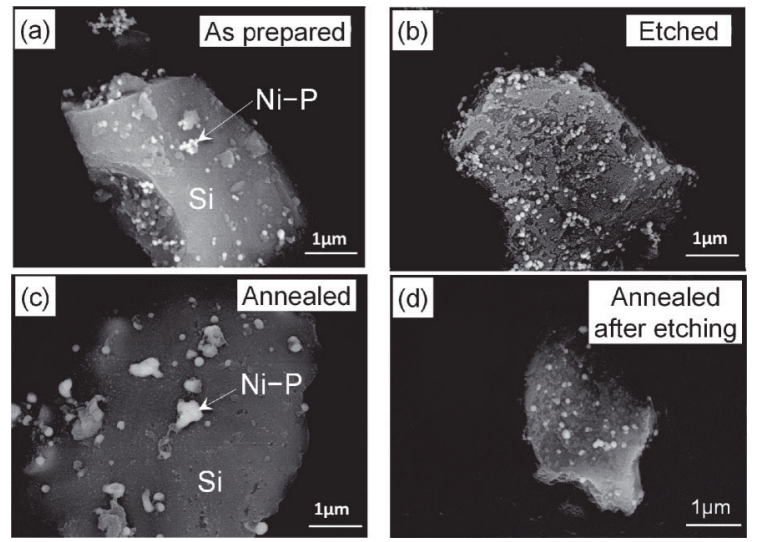

Fig. 2. (color online). Backscattered electron images of $\mathrm{Ni}^{-}$ $\mathrm{P} / \mathrm{Si}$ particles (a) as prepared, (b) with etched surface of $\mathrm{Si}$, (c) annealed at $800^{\circ} \mathrm{C}$, and (d) annealed at $800^{\circ} \mathrm{C}$ after the surface etching.

層と $\mathrm{Si}$ 粒子との密着性が向上しているものと期待され る。

Fig. 2 は処理の内容が異なる四種類の $\mathrm{Ni}-\mathrm{P} / \mathrm{Si}$ 粒子の SEM 観察で得られた反射電子像を示す。元素分析の結

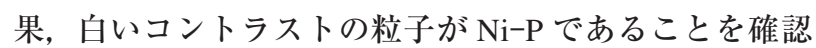
した。いずれの処理も行っていない粒子では数 $10 \mathrm{~nm}$ の大きさの $\mathrm{Ni}-\mathrm{P}$ 粒子が平滑な $\mathrm{Si}$ 表面上に斑点状に析出 している様子が観察された（Fig. 2（a）。エッチング処 理を行った試料では，同様の $\mathrm{Ni}-\mathrm{P}$ 粒子が凹凸の多い $\mathrm{Si}$ 粒子表面上に析出していることがわかった（Fig.2 (b) )。 $800^{\circ} \mathrm{C}$ での熱処理を行った試料では， Ni-P 粒子の 析出がより疎になっていることと, $300 \mathrm{~nm}$ 以上の大き な粒子が存在することが確認された（Fig. 2 (c))。これ は熱エネルギーにより $\mathrm{Ni}$ が $\mathrm{Si}$ 粒子内に拡散するととも に隣接する $\mathrm{Ni}-\mathrm{P}$ 粒子同士が凝集したためと推察され る。これに対し，あらかじめ表面粗化処理を行ったうえ で熱処理を実施した試料では, 析出密度は多少低下して いるように見受けられるものの粒子の凝集は見られなか った（Fig. 2(d))。

\section{2 熱処理と表面粗化処理が負極性能に与える影響}

Fig. 3 は四種類の Ni-P/Si 粒子を用いて作製したコン ポジット電極に対する, 従来の有機溶媒電解液中での初 回サイクルにおける充放電曲線を示す。比較として Si 単独電極の結果も併せて示す。いずれの電極において も, 充電 ( $\mathrm{Li}$ 扱入) 側 $0.1 \mathrm{~V}$ と放電 ( $\mathrm{Li}$ 脱離) 側 $0.4 \mathrm{~V}$ 付近において，それぞれ $\mathrm{Si}$ の Li との合金化一脱合金化 に起因する電位平坦部が観測された。 $\mathrm{Ni}-\mathrm{P}$ 被覆層中の $\mathrm{Ni}$ は Li 不活性な物質であるにもかかわらずコンポジッ 卜電極が可逆的な Li 吸蔵一放出反応を示したのは, 被 覆層中の $\mathrm{Ni}_{3} \mathrm{P}$ が適度な $\mathrm{Li}$ 反応性を有することと ${ }^{5)}, \mathrm{Ni}^{-}$

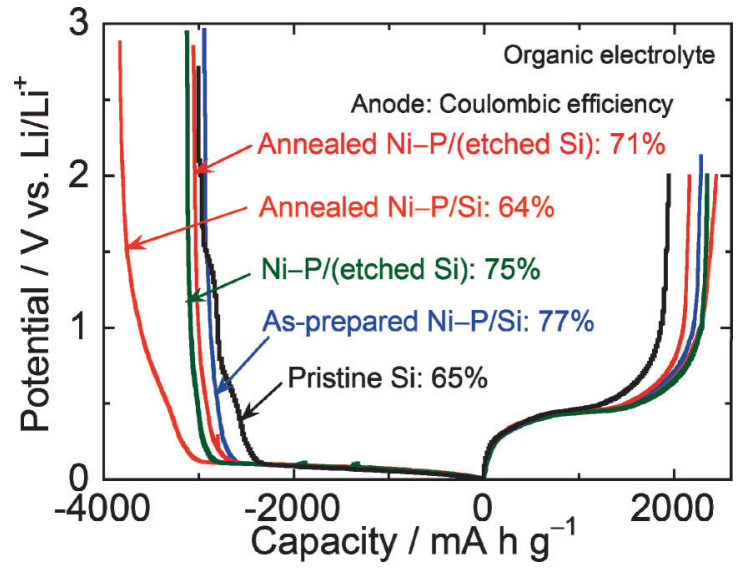

Fig. 3. (color online). Initial charge-discharge curves and Coulombic efficiency of composite electrode consisting of various $\mathrm{Ni}-\mathrm{P} / \mathrm{Si}$ particles in conventional organic electrolyte.

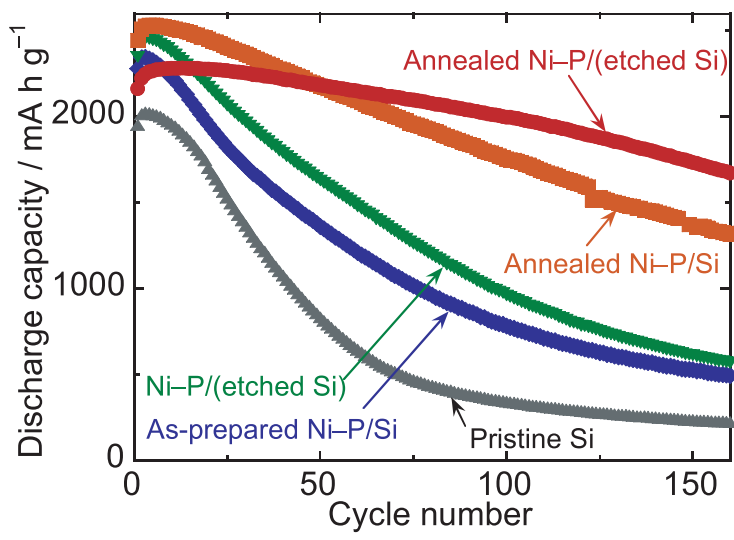

Fig. 4. (color online). Cycling performances of thick-film electrode consisting of $\mathrm{Ni}-\mathrm{P} / \mathrm{Si}$ particles prepared by ELD of $\mathrm{Ni}-\mathrm{P}$ on etched $\mathrm{Si}$ surface and by subsequent annealing at $800^{\circ} \mathrm{C}$.

$\mathrm{P}$ の析出形状が斑点状であるため $\mathrm{Si}$ 粒子表面が露出し た部位が多く存在することによるものと考えられる。充 電容量に対する放電容量の割合 (クーロン効率) に関し ては, 熱処理のみを行ったコンポジット電極以外では改 善が見られた。これは, 電解液の分解等の副反応が起き やすい $\mathrm{Si}$ 表面の露出面積が $\mathrm{Ni}-\mathrm{P}$ の被覆により減少した ためと推測される。

Fig. 4 はこれらの電極の充放電サイクルにともなう放 電容量の推移を示す。Si 単独電極では 100 サイクルに 至るまでに急激な容量衰退が見られ，そしいサイクル安 定性しか得られなかった。この容量衰退の主要因は, Li 吸蔵一放出の際の大きな体積変化に起因する活物質層の 崩壊と思われる。Si の体積変化により永久ひずみが活 物質層内に蓄積され，これが限界值を超えた際に活物質 
層が破壊されその一部が電気的に孤立し Li を吸蔵一放 出できなくなるため, サイクルが進むにつれ容量が徐々 に減少するものと考えられる。Si 単独電極の結果に対 し, 未処理の $\mathrm{Ni}-\mathrm{P} / \mathrm{Si}$ 粒子を用いた電極では容量衰退に 若干の改善が見られた。 $\mathrm{Si} へ の \mathrm{Ni}-\mathrm{P}$ 被覆には活物質層 の機械的性質を改善させるだけでなく, 電子伝導性を約 80 倍向上させる効果があることが著者らの実験により 確かめられている。これらの協奏効果のため, $\mathrm{Si}$ の体 積変化による活物質層の崩壊と電気的孤立を低減できた ものと考えられる。これに熱処理を行うとさらなる改善 が見られ，150サイクル後においても $1350 \mathrm{~mA} \mathrm{~h} \mathrm{~g}^{-1}$ の 放電容量を維持した。これは，熱処理により $\mathrm{Ni}-\mathrm{P}$ 中の $\mathrm{Ni}$ の一部が $\mathrm{Si}$ 内一拡散したことで界面の密着性が向上 し, $\mathrm{Si}$ の激しい体積変化が起こってもその表面から $\mathrm{Ni}^{-}$ $\mathrm{P}$ が剥離することなく長期サイクルにわたり被覆層とし て存在し活物質層の崩壊を抑制できたことが要因と推察 される。これを確かめるため充放電後の活物質層の表面 粗さを共焦点走查型レーザー顕微鏡により正確に測定し た。その結果, 100 サイクル後の表面粗さは熱処理なし の電極では $6.05 \pm 0.38 \mu \mathrm{m}$ であったが, 熱处理を行うこ とで $4.00 \pm 0.76 \mu \mathrm{m}$ に低減されており活物質層の崩壊が 抑制されていることを確認した。熱処理を行った電極で 123 サイクルと 147 サイクルに見られた不連続的な容量 衰退は，それまでに蓄積された永久ひずみによって偶発 的にこれらのサイクルにおいてより顕著に活物質層の崩 壊が進んだことを示しているものと思われる。

エッチング処理だけを行った $\mathrm{Ni}-\mathrm{P} / \mathrm{Si}$ 粒子からなる電 極は未処理のものと同程度のサイクル性能であり, 表面 粗化が負極性能に与える効果は見られなかった。ところ が，これにさらに熱処理を行ってみたところサイクル安 定性が大幅に向上し，150 サイクル後でも 1730 $\mathrm{mA} \mathrm{h} \mathrm{g}^{-1}$ の高容量を保持する最も優れた負極性能を発 揮することがわかった。他の電極とは異なり，150 サイ クルの時点でもまだ本格的な容量衰退が見られないこと は, 活物質層の崩壊の進行を大幅に食い止められている ことを示すものである。以上の結果より，凹凸の多い $\mathrm{Si}$ 表面に $\mathrm{Ni}-\mathrm{P}$ を析出させただけでは密着性の向上には 至らなかったが，これに対し熱処理を行うと $\mathrm{Ni}$ が荒れ た $\mathrm{Si}$ 表面へ拡散することでアンカー効果が働き一層の 密着性の向上とこれによる電極耐久性の改善が害現でき たものと考えられる。

\section{3 イオン液体電解液の適用による界面の最適化}

電気化学的安定性に優れるイオン液体を電解液に適用 すると，有機溶媒を用いた場合よりも均一な被膜が $\mathrm{Si}$ 表面上に形成されることで電極表面全体での均一な $\mathrm{Li}$ 挿入一脱離が起こり, 電極崩壊が抑制されることを示す

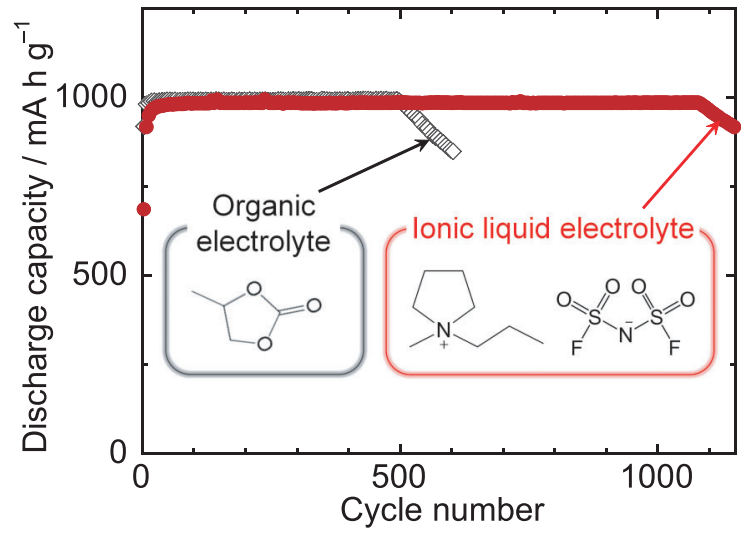

Fig. 5. (color online). Cycling performances of electrodes consisting of annealed $\mathrm{Ni}-\mathrm{P} /$ (etched $\mathrm{Si}$ ) in ionic liquid electrolyte (LiTFSA/Py13-FSA) and conventional organic electrolyte (LiTFSA/PC). The charge capacities were limited to $1000 \mathrm{~mA} \mathrm{~h} \mathrm{~g}^{-1}$.

結果を得ている ${ }^{20)}$ 。そこで本研究において最も良好な性 能を示した両処理を行った $\mathrm{Ni}-\mathrm{P} / \mathrm{Si}$ からなるコンポジッ 卜電極に対して, イオン液体電解液を適用しその負極性 能を調べた。その結果, 有機電解液中での 150 サイクル 後に扔ける容量維持率は $80 \%$ であったのに対し, イオ ン液体電解液を適用した場合にはこれが $92 \%$ にまで改 善されることがわかった。しかしながら，それでもなお 各サイクルごとに容量が徐々に失われる現象は避けられ ない結果となった。還元分解に強いイオン液体を用い負 極表面上に均一な被膜を形成してもこのような結果を招 いたのは，負極表面全体で均質に Li との合金化一脱合 金化反応が起きても $\mathrm{Si}$ の体積変化が大き過ぎる場合に はその効用を活かしきれないためと考えた。そこで，電 解液にイオン液体を用いた効果がより強く現れることを 期待して，Li 抻入量を $1000 \mathrm{~mA} \mathrm{~h} \mathrm{~g}^{-1}$ 以下に制限し $\mathrm{Si}$ の体積変化を抑えた条件下で充放電試験を行った。その 結果を Fig. 5 に示す。有機電解液中では 500 サイクル目 から容量の衰退が始まったのに対し，イオン液体電解液 を適用した場合には 1100 サイクルもの非常に長いサイ クルにわたり $1000 \mathrm{~mA} \mathrm{~h} \mathrm{~g}^{-1}$ の容量をまったく損なうこ となく維持し, 特筆すべき高いサイクル安定性を示し た。現行の黒鉛負極の理論容量の 2.7 倍に相当する放電 容量を長期間維持できたことは特筆すべき結果である。

\section{4. を め}

次世代リチウムイオン電池の開発には従来の黒鉛負極 から高容量 $\mathrm{Si}$ 系負極への転換が必要である。著者らは その高容量を十分に発揮させるには，Si の欠点を補う ための負極活物質のコンポジット化だけでなく, 電極一 
電解質界面の最適化も重要であると考えている。本研究 では，これまでに著者らが見いだしてきた $\mathrm{Ni}-\mathrm{P}$ 被覆 $\mathrm{Si}$ コンポジット電極の活物質粉末に対し表面粗化処理と熱 処理を行うことで $\mathrm{Ni}-\mathrm{P}$ 被覆層と $\mathrm{Si}$ 粒子との間の密着性 を改善でき，これによりその負極性能が大きく向上する ことを見いだした。これに加え, イオン液体電解液を適 用することで $1000 \mathrm{~mA} \mathrm{~h} \mathrm{~g}^{-1}$ もの高容量を 1100 サイク ルという長い期間維持することに成功した。

\section{謝辞}

本研究の一部は日本学術振興会科学研究費助成事業 （課題番号 24350094）の助成を受けて実施されたもので ある。関係各位に深く感謝する。

\section{文献}

1) H. Sakaguchi, T. Toda, Y. Nagao and T. Esaka : Electrochem. Solid-State Lett. 10, J146 (2007).

2) 坂口裕樹ら : 特許第 4626966 号 (2010).

3) H. Usui, Y. Kashiwa, T. Iida and H. Sakaguchi : J. Power Sources 195, 3649 (2010).

4) H. Usui, H. Nishinami, T. Iida and H. Sakaguchi : Electrochemistry 78, 329 (2010).

5) H. Usui, M. Shibata, K. Nakai and H. Sakaguchi : J. Power Sources 196, 2143 (2011).

6) H. Usui, N. Uchida and H. Sakaguchi : J. Power Sources 196, 10244 (2011).

7) H. Usui, N. Uchida and H. Sakaguchi : Electrochemistry 80, 737 (2012).

8) T. Iida, T. Hirono, N. Shibamura and H. Sakaguchi :
Electrochemistry 76, 644 (2008).

9) H. Sakaguchi, T. Iida, M. Itoh, N. Shibamura and T. Hirono : IOP Conf. Series : Mater. Sci. Eng. 1, 012030-1 (2009).

10) H. Usui, K. Maebara, K. Nakai and H. Sakaguchi : Int. J. Electrochem. Sci. 6, 2246 (2011).

11) H. Sakaguchi and H. Usui : Electrochemistry 80, 45 (2012).

12) H. Usui, M. Nomura, H. Nishino, M. Kusatsu, T. Murota and H. Sakaguchi : Mater. Lett. 130, 61 (2014).

13) H. Usui, K. Nouno, Y. Takemoto, K. Nakada, A. Ishii and H. Sakaguchi : J. Power Sources 268, 848 (2014).

14) H. Usui, T. Kono and H. Sakaguchi : Int. J. Electrochem. Sci. 7, 4322 (2012).

15) H. Usui, K. Wasada, M. Shimizu and H. Sakaguchi : Electrochim. Acta 111, 575 (2013).

16) H. Usui, Y. Yamamoto, K. Yoshiyama, T. Itoh and H. Sakaguchi : J. Power Sources 196, 3911 (2011).

17) H. Usui, T. Masuda and H. Sakaguchi : Chem. Lett. 41, 521 (2012).

18) H. Usui, M. Shimizu and H. Sakaguchi : J. Power Sources 235, 29 (2013).

19) M. Shimizu, H. Usui, K. Matsumoto, T. Nokami, T. Itoh and H. Sakaguchi: J. Electrochem. Soc. 161, A1765 (2014).

20) M. Shimizu, H. Usui, T. Suzumura and H. Sakaguchi : J. Phys. Chem. C 119, 2975 (2015).

21) C.M. Liu, W.L. Liu, S.H. Hsieh, T.K. Tsai and W.J. Chen : Appl. Surf. Sci. 243, 259 (2005).

22) H.F. Hsu, H.Y. Chan, T.H. Chen, H.Y. Wu, S.L. Cheng, F.B. Wu : Appl. Surf. Sci. 257, 7422 (2011). 